\title{
Predictors of postoperative mortality in ruptured aneurysms of internal carotid artery
}

\section{Czynniki rokownicze śmiertelności po operacii pękniętych tętniaków tętnicy szyjnej wewnętrznej}

Tomasz Szmuda, Paweł Słoniewski, Jarosław Dzierżanowski, Marcin Ru†

Katedra i Klinika Neurochirurgii, Gdański Uniwersytet Medyczny

Neurologia i Neurochirurgia Polska 2011; 45, 6: 543-555

\section{Abstract}

Background and purpose: An analysis of predictors of mortality in patients with ruptured intracranial aneurysm is an important aspect in the assessment of outcome. The aim of the study was to analyse factors determining mortality risk after the surgical treatment of ruptured internal carotid artery (ICA) aneurysm.

Material and methods: This study comprised 242 patients operated on between 1997 and 2006 in the Neurosurgery Department of the Medical University Hospital in Gdansk, Poland. Multivariate logistic regression, ROC curves (for model assessment as a mortality classifier) and population attributable risk for contribution of individual factor mortality explanation were used to assess factors related to in-hospital mortality.

Results: $14.9 \%$ of patients died postoperatively. In univariate analysis, increased risk of death was related to the Glasgow Coma Scale score, WFNS score, Hunt-Hess and Fisher grade, preoperative neurological deficit, delayed cerebral ischaemia (DCI), trapping and bypass operative method. Multivariate analysis revealed two independent predictors of in-hospital mortality: DCI and Hunt-Hess grade. $91 \%$ of mortality risk was attributed to grade 4 or 5 in Hunt-Hess scale and DCI. The dominant predictor of survival was the Hunt-Hess scale. Increase by one grade in the Hunt-Hess scale resulted in twofold increase of in-hospital mortality risk.

Conclusions: Postoperative mortality after ICA aneurysm rupture is determined by clinical status at admission and the occurrence of DCI.

\section{Streszczenie}

Wstęp i cel pracy: Analiza czynnikowa śmiertelności wśród chorych z pękniętym tętniakiem wewnątrzczaszkowym stanowi ważny aspekt w ocenie wyników leczenia. Celem pracy była analiza czynników mających wpływ na zwiększone ryzyko zgonu po operacji krwawiącego tętniaka tętnicy szyjnej wewnętrznej. Materiał i metody: W badaniu wzięło udział 242 chorych operowanych w latach 1997-2006 w Klinice Neurochirurgii Gdańskiego Uniwersytetu Medycznego. Czynniki rokownicze śmiertelności w tej grupie analizowano za pomocą wieloczynnikowej regresji logistycznej, porównania krzywych ROC (celem oceny poprawności całego modelu jako klasyfikatora śmiertelności) i wskaźników ryzyka przypisanego populacji (PAR) dla wskazania udziału poszczególnych czynników w wyjaśnieniu śmiertelności. Analizowano jedynie przypadki zgonów występujące w trakcie hospitalizacji.

Wyniki: Śmiertelność pooperacyjna wyniosła 14,9\%. W analizie jednoczynnikowej ryzyko zgonu zależało od: stopnia w skali śpiączki Glasgow, punktacji w skali WFNS, Hunta-Hessa, Fishera, przedoperacyjnego deficytu neurologicznego, rozpoznania opóźnionego niedokrwienia mózgu (delayed cerebral ischaemia - DCI), metody operacyjnej polegającej na zamknięciu naczynia lub wytworzeniu obejścia naczyniowego. Spośród nich analiza wieloczynnikowa wyłoniła dwie niezależne zmienne, które miały istotny wpływ na śmiertelność: DCI oraz stan kliniczny pacjentów przy przyjęciu mierzony w skali Hunta-Hessa. Stopień 4. i 5. w tej skali oraz rozpoznanie DCI odpowiadały za $91 \%$ ryzyka zgonu po operacji

Correspondence address: Tomasz Szmuda, Katedra i Klinika Neurochirurgii, Gdański Uniwersytet Medyczny, ul. Dębinki 7, 80-952 Gdańsk, phone +485834923 30, fax + 485834558 88, e-mail: tszmuda@gumed.edu.pl

Received: 27.02.2011; accepted: 20.06.2011 
Key words: brain aneurysm, subarachnoid haemorrhage, internal carotid artery, mortality, outcome.

\section{Introduction}

The history of aneurysms' treatment dates back to the $18^{\text {th }}$ century. Then, for the first time, internal carotid artery (ICA) ligation was attempted as a medical treatment. Accordingly, Dandy in 1936 made a breakthrough when he ligatured the ICA rostral and caudal to the neck of the aneurysm adjacent to the cavernous sinus; a year later he clipped the ICA aneurysm neck with a Cushing silver clip [1]. Yasargil described his improved pterional craniotomy in 1969; it has been used since as an approach for the majority of intracranial aneurysms [2]. Yasargil's legacy in the development of intracranial aneurysms' treatment is very significant. He developed so-called "floating microscope", currently a standard in the neurosurgical operative theatre, improved microsurgical instrumentation and designed a plethora of vascular clips along with instruments for their application [3]. He described microsurgical methods that spare brain tissue on the approach to the pathology and performed the first experimental bypass between the superficial temporal artery and middle cerebral artery in $1970[3,4]$.

Endovascular treatment is a current alternative for surgical disconnection of ruptured aneurysms from the circulation. The aim of the treatment remains the same, i.e. the disconnection of the aneurysm from the circulation while ensuring blood flow through the native vessel and perforators, which originate from it $[3,5,6]$. The outcome of surgical and endovascular techniques, despite their constant development, is comparable [5-7].

The decision whether endovascular or surgical technique is superior in the treatment of aneurysms remains a constant and inextricable subject of debate in neurosurgery $[8,9]$. The multicenter study ISUIA [10] proved that the risk of rupture of the smaller aneurysm varied between 2.5 and $40 \%$ in five-year follow-up and thus necessitated treatment for the majority of patients with tętniaka tętnicy szyjnej wewnętrznej. Dominujące znaczenie w przewidywaniu przeżycia miała skala Hunta-Hessa. Ocena stanu klinicznego chorego o jeden stopień wyżej w tej skali zwiększała ponaddwukrotnie ryzyko zgonu pooperacyjnego. Wnioski: Śmiertelność pooperacyjna po pęknięciu tętniaka tętnicy szyjnej wewnętrznej uwarunkowana jest stanem klinicznym przy przyjęciu i wystąpieniem DCI.

Słowa kluczowe: tętniak wewnątrzczaszkowy, krwawienie podpajęczynówkowe, tętnica szyjna wewnętrzna, śmiertelność, wyniki leczenia.

radiologically diagnosed intracranial aneurysms. Surgical treatment of unruptured, intracranial aneurysms carries relatively low mortality that does not exceed 2\% [9].

Rupture of an intracranial aneurysm results in subarachnoid haemorrhage (SAH). Annual morbidity of SAH varies between 6 and 8 cases per $100000[9,11]$ while in Finnish and Japanese populations this value might be several times higher [11]. Prognosis for ruptured intracranial aneurysm is unfavourable: two-thirds of all patients succumb to the disease or are left with disability [3].

Postoperative mortality analysis in intracranial aneurysms after surgical or endovascular treatment remains a principal assessment of the therapeutic modalities in neurosurgery $[7,9,12]$. Kassell's multicenter study proved that a favourable outcome of surgical treatment of ruptured aneurysms relies on factors directly related to $\mathrm{SAH}$, aneurysm localization, age or coexisting diseases. Subsequent publications partially confirmed the role of factors initially listed by Kassell and introduced new prognostic variables; still the analysis always embraced patients with all localizations of intracranial aneurysms $[7,9,12$, 15-19]. In our opinion, it would be of value to perform an analysis of factors that might influence the outcome of patients following SAH from a selected artery such as the internal carotid artery (ICA), which is one of the most common localizations of intracranial aneurysms $[3,4]$. An important cause of increased mortality relates to the occurrence of vasospasm that follows SAH [16, $18,19]$. Internal carotid artery aneurysm's rupture most often fills basal cisterns with blood [3], which consequently makes factorial analysis of mortality for this aneurysm localization more reliable.

A widespread view in the neurosurgical community $[3,4]$ advocates that the size of the aneurysm constitutes an important prognostic factor. Surgery for ruptured giant aneurysm, according to a number of authors $[9,20-22]$, is associated with higher mortality, which might 
reach 30\% [21]. The authors suggest that the rationale for failure of surgical management of these aneurysms includes deficiency of surgical techniques $[6,22]$ and, according to some of them, higher amount of extravasated blood $[4,23,24]$. Some of the papers stress that a proper treatment strategy might significantly improve outcome of surgical treatment of giant aneurysms [22]. In our opinion this justifies the analysis of the influence of the aneurysm size on postoperative mortality in our centre.

\section{Material and methods}

\section{Patients}

A total of 1035 intracranial aneurysm operations were performed in the Department of Neurosurgery of Gdansk Medical University between 1997 and 2006. Retrospective analysis involved a homogeneous group of 281 patients with ruptured intracranial aneurysms of the ICA. Multiple ruptured aneurysms ( $n=34)$, one intracavernous ruptured aneurysm and 4 cases of blood blister-like ICA aneurysms were excluded from the analysis. Patients with multiple aneurysms were excluded from our cohort when ICA aneurysm was treated simultaneously with another intracranial aneurysm. Analysis of morbidity encompassed patients with ruptured ICA aneurysm when another aneurysm (assessed preoperatively as non-ruptured, accidentally found) was treated a few months later. The final cohort included 242 patients treated for ruptured saccular ICA aneurysm, which constitutes $23.4 \%$ of aneurysm surgery in our department.

We elected a group of ICA aneurysms for further analysis due to the following reasons: (1) ICA constitutes one of the most common localizations of intracranial aneurysms; (2) basal cisterns fill with blood in patients with ruptured aneurysms located proximally to the middle cerebral artery, which conversely increases the proportion of patients with vasospasm $[16,25,26]$; (3) ruptured ICA aneurysms have similar blood distribution within basal cisterns, which produces a similar outcome; (4) Kassell [13] proved that mortality depended on aneurysm's localization. In his hands, mortality varied from $20 \%$ (middle cerebral artery), $24 \%$ (ICA) to $30.5 \%$ (anterior communicating artery and basal artery); and (5) to the best of our knowledge, no reports exist that specifically address mortality risk factors following SAH from ruptured aneurysms at the same location.

The age of patients in our cohort averaged 51.7 years (standard deviation [SD], 12.4) and ranged from 17 to 83 years. Women constituted the majority of cases $(n=186 ; 76.9 \%)$. One hundred and twenty-seven patients $(52.5 \%)$ had secondary or higher education while 115 patients $(47.5 \%)$ had professional or lower education. Only $21 \%(n=51)$ of patients lived in rural areas.

Our group included 36 giant aneurysms (diameter exceeding $25 \mathrm{~mm}$ ) (14.9\% of patients) and 206 smaller aneurysms. Artery segments occupied by giant ICA aneurysms differed from smaller aneurysms $(p<0.01)$, probably due to the different mechanism of development of giant ICA aneurysms [27]. Giant aneurysms were more prevalent in the clinoid segment $(1-\beta=91.9 \%)$ and were smaller in the supraclinoid segment $(1-\beta=94.7 \%)$ (see Fig. 1).

Clinical status of the patients was evaluated on admission. Post-SAH clinical status was judged based on the Hunt-Hess scale with Kosnik's modification [28,29]. Consciousness level was assessed on admission based on the Glasgow Coma Scale (GCS) [30] and World Federation of Neurosurgeons Scale (WFNS) [31]. For grading in the WFNS and Hunt-Hess scales, an examination for focal neurological deficits was necessary. The extent of bleeding was radiologically appraised according to the Fisher scale, based on the initial CT scan that confirmed SAH (Table 1) [25].

Most of the patients in our cohort $(n=150,62.0 \%)$ presented with other systemic illnesses such as hypertension, coronary heart disease and depression.

\section{Surgical methods}

A fronto-temporal approach was usually implemented; in 3 cases it was extended to an orbito-zygomatic approach in the modification published by us previously [32]. Extended craniotomy in each case involved an additional extradural, partial osteotomy of the lesser wing and superior orbital fissure decompression that widened the access. In selected cases, mainly in giant aneurysms of the clinoid segment, extradural resection of the anterior clinoid process $(\mathrm{ACP})$ with concomitant optic canal opening was performed. The surgery always aimed at the clipping of the aneurysm's neck. If preoperative, rarely intraoperative, estimation proved clipping to be not feasible, an ICA trapping with bypass was performed. Wrapping of the aneurysm was an optional method of securing it. Microvascular, intraoperative Doppler examination was performed in order to ensure ICA patency and aneurysm's occlusion. In selected cases of giant aneurysms various supplemental methods were instigated. Surgical modalities in the treatment of giant aneurysms $(n=36)$ were significantly different from those implemented in or- 


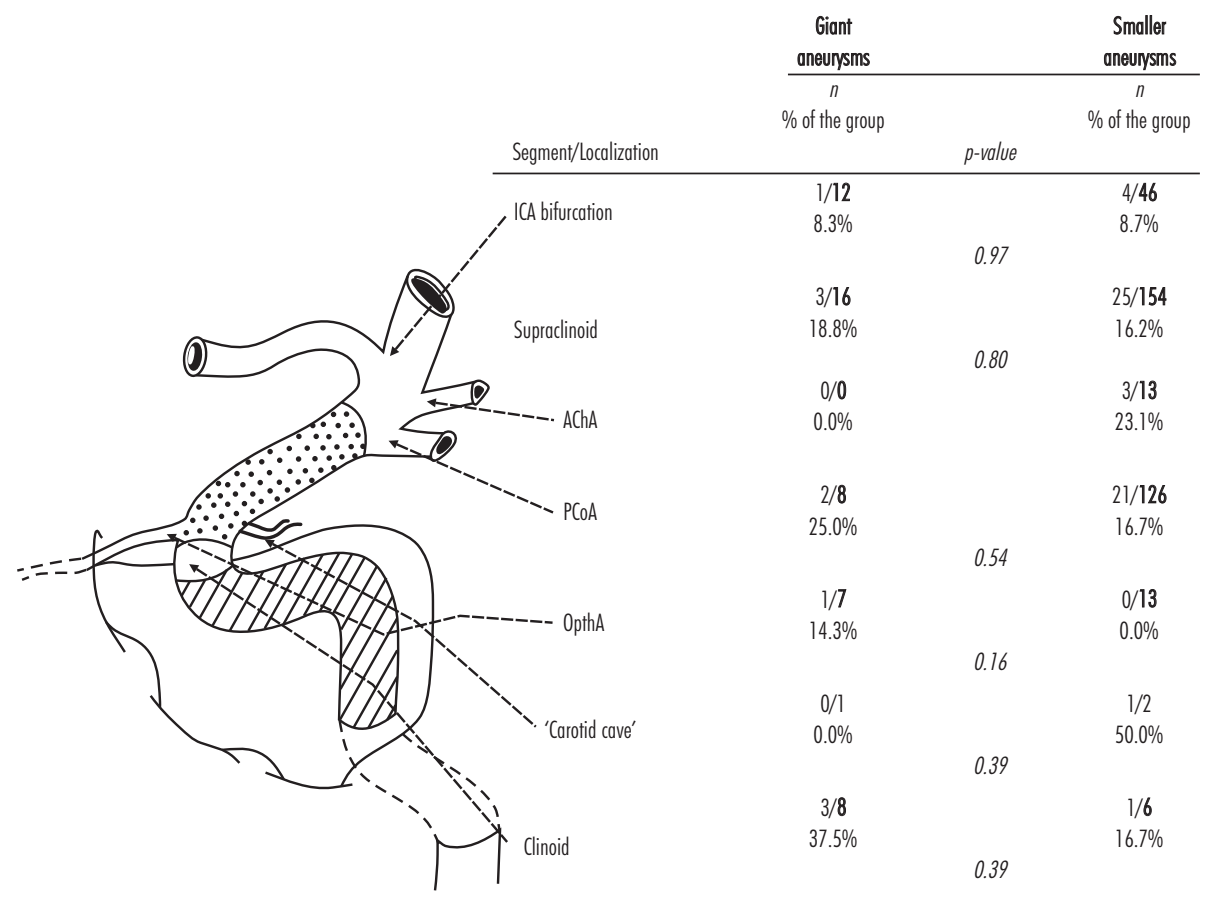

AChA - anterior choroid artery, PCOA - posterior communicating artery, OphtA - ophtalmic artery

Fig. 1. Number of cases (dead/all) and percentage of deaths for individual localisation of giant and smaller internal carotid artery aneurysms. P-value is marked for comparison of individual aneurysm localisation

Table 1. Clinical condition and radiological assessment at admission

\begin{tabular}{|ll|}
\hline Variable & $\mathbf{n}(\%)$ \\
\hline Neurological deficit & $17(7.0 \%)$ \\
\hline Hemiparesis & $8(3.3 \%)$ \\
\hline Aphasia & $13(5.4 \%)$ \\
\hline Third nerve palsy & $2(0.8 \%)$ \\
\hline Sixth nerve palsy & $5(2.1 \%)$ \\
\hline Unspecified visual symptoms & $198(81.8 \%)$ \\
\hline No focal neurological deficits & $148(61.2 \%)$ \\
\hline World Federation of Neurosurgeons (WFNS) scale \\
\hline Grade I & $10(4.1 \%)$ \\
\hline Grade II & $12(5.0 \%)$ \\
\hline Grade III & $56(23.1 \%)$ \\
\hline Grade IV & $16(6.6 \%)$ \\
\hline Grade V & $7(2.9 \%)$ \\
\hline Fisher scale & $133(54.9 \%)$ \\
\hline Grade 1 & $82(33.9 \%)$ \\
\hline Grade 2 & $20(8.3 \%)$ \\
\hline Grade 3 & $49(20.2 \%)$ \\
\hline Grade 4 & $10(4.1 \%)$ \\
\hline Hunt-Hess scale & $88(36.4 \%)$ \\
\hline Grade 1 & $43(17.8 \%)$ \\
\hline Grade 1A & $37(15.3 \%)$ \\
\hline Grade 2 & $15(6.2 \%)$ \\
\hline Grade 3 & \\
\hline Grade 4 & \\
\hline Grade 5 & \\
\hline
\end{tabular}

der to secure smaller ones $(n=206, p<0.01)$. Smaller aneurysms were clipped more often $(1-\beta=68.8 \%)$, while a bypass was performed only in selected cases of giant ICA aneurysms $(1-\beta=82.2 \%)$.

Surgery of smaller aneurysms was performed by 7 neurosurgeons while giant ones were treated by one author (PS) (Table 2). Only clinically significant surgical complications were analysed (Table 3).

Neurological status was evaluated again during hospitalization and compared with neurological status on admission. Delayed cerebral ischaemia (DCI), defined as the occurrence of new, focal neurological deficits and/or consciousness level deterioration during hospitalization, was found in 23 patients, which constituted $9.5 \%$ of the group.

Definitions of perioperative (within $48 \mathrm{~h}$ after surgery) and postoperative (more than $48 \mathrm{~h}$ after surgery) death were adopted from the Joint Commission on Accreditation of Healthcare Organizations classification [33]. Only death cases that occurred during hospitalization in the department were analysed.

Primarily, in order to ensure proper selection of statistical tests, normal distribution of continuous variables was verified with Kolmogorov-Smirnov test with Lilliefors correction. For categorical variables, depending on the 
Table 2. Operative methods and accessory techniques

\begin{tabular}{|c|c|c|}
\hline & $\begin{array}{c}\text { Giant ICA aneurysms } \\
(n=36) \\
n(\%)\end{array}$ & $\begin{array}{c}\text { Small ICA aneurysms } \\
(n=206) \\
n(\%)\end{array}$ \\
\hline \multicolumn{3}{|l|}{ Surgical approach } \\
\hline Pterional craniotomy & $34(94.4 \%)$ & $205(99.5 \%)$ \\
\hline Extended orbito-zygomatic pterional approach & $2(5.6 \%)$ & $1(0.5 \%)$ \\
\hline \multicolumn{3}{|l|}{ Additional osteotomy } \\
\hline ACP osteotomy & $7(19.4 \%)$ & $7(3.4 \%)$ \\
\hline Optic nerve canal opening & $1(2.8 \%)$ & 0 \\
\hline \multicolumn{3}{|l|}{ Surgical modality implemented } \\
\hline Clipping* & $30(83.3 \%)$ & $196(95.1 \%)$ \\
\hline Trapping & 0 & $3(1.5 \%)$ \\
\hline Wrapping & $1(2.8 \%)$ & $4(1.9 \%)$ \\
\hline Revision only (clipping not feasible) & $2(5.6 \%)$ & $3(1.5 \%)$ \\
\hline ECA-MCA bypass* & $3(8.3 \%)$ & 0 \\
\hline \multicolumn{3}{|l|}{ Supportive methods } \\
\hline Retrograde suction & $2(5.6 \%)$ & 0 \\
\hline Endovascular balloon & $1(2.8 \%)$ & 0 \\
\hline
\end{tabular}

$I C A$ - internal carotid artery, $A C P$ - anterior clinoid process, ECA-MCA - external carotid artery to middle cerebral artery

*Significant differences between operative methods and aneurysm size groups

size of the group and expected values, chi-square with or without Yates correction, V-square or Fisher's exact test was implemented. Conclusions for aforementioned tests were based on differences between observed and theoretical frequencies. Comparisons of continuous variables were performed with Student's $t$-test or its non-parametric equivalent, Mann-Whitney U-test. A probability value was assessed for all relationships between continuous variables. Comparisons in univariate analyses for which test power (1- $\beta$ ) exceeded $80 \%$ were considered significant. Multivariate analysis was based on a logistic regression model with Quasi-Newton estimation. Non-significant factors $(p \geq 0.05)$ were successively excluded from the analysis in order to attain a hierarchical logistic regression model. Confidence intervals (CI) for odds ratios were established at $95 \%$; each hypothesis was verified at the $p \leq 0.05$ level of confidence. A receiver operating characteristics (ROC) curve was created and area under curve (AUC) was calculated. Described tools (ROC and AUC) were subsequently applied in order to verify the correctness of the whole model as a mortality classifier. Population attributable risk (PAR) was calculated in order to assess the percentage of mortality reduction if given risk factors had not existed. Statistical analysis was performed with Statistica v.9.0 (basic statistics and the power of tests), Med Calc v.11.4 (ROC curve analysis) and StatsDirect v.2.7.8 (PAR calculation and their CI for retrospective analysis).
Table 3. Operative complications (surgical and general)

\begin{tabular}{|lc|}
\hline \multicolumn{1}{|c|}{ Complication type } & $\begin{array}{c}\text { Analysed group } \\
\mathbf{( n = 2 4 2 )} \\
\mathbf{n}(\mathbf{\%})\end{array}$ \\
\hline $\begin{array}{l}\text { Surgical } \\
\text { Haematoma that required surgical treatment }\end{array}$ & $2(2.1 \%)$ \\
$\begin{array}{l}\text { Wound infection that required surgical } \\
\text { debridement }\end{array}$ & $1(0.4 \%)$ \\
\hline Rhinorrhea & $1(0.4 \%)$ \\
\hline Subgaleal fluid collection & $1(0.4 \%)$ \\
\hline General & $7(2.9 \%)$ \\
\hline Myocardial infarction & $1(0.4 \%)$ \\
\hline Infection treated conservatively & $5(2.1 \%)$ \\
\hline meningitis & $2(0.8 \%)$ \\
\hline pneumonia & $2(0.8 \%)$ \\
\hline urinary tract infection & $1(0.4 \%)$ \\
\hline Pulmonary embolism & $1(0.4 \%)$ \\
\hline Total & $12(5.0 \%)$ \\
\hline
\end{tabular}

\section{Results}

\section{Homogeneity of the group}

At first, an analysis of homogeneity of our group of surgically treated, ruptured ICA aneurysms was performed with subsequent correlative studies between demographic factors, localization, performing surgeon, clinical status and SAH intensity (Hunt-Hess, GCS, 
Table 4. Homogeneity analysis of the group. Correlation between demographic factors, localisation of aneurysm, surgeon and clinical condition and radiological assessment on admission $(n=242)$

\begin{tabular}{|lllllc|}
\hline & Hunt-Hess scale & GCS & WFNS & Fisher scale & $\begin{array}{c}\text { Neurological symptoms } \\
\text { prior to surgery }\end{array}$ \\
\hline Age & 0.14 & 0.61 & 0.55 & 0.69 & 0.24 \\
\hline Sex & 0.91 & 0.45 & 0.22 & 0.23 & 0.53 \\
\hline Education & 0.17 & 0.73 & 0.30 & 0.87 & 0.25 \\
\hline Place of residence (countryside/town) & 0.94 & 0.85 & 0.38 & 0.82 & 0.51 \\
\hline Coexisting diseases & 0.63 & 0.70 & 0.84 & 0.57 & 0.50 \\
\hline Side & 0.24 & 0.36 & 0.20 & 0.72 & 0.24 \\
\hline ICA segment & 0.78 & 0.28 & 0.68 & 0.41 & 0.36 \\
\hline Detailed location & 0.56 & 0.28 & 0.46 & 0.10 & 0.56 \\
\hline Year of operation & 0.44 & 0.77 & 0.78 & 0.82 & 0.37 \\
\hline Surgeon & 0.22 & 0.06 & 0.17 & 0.12 & 0.08 \\
\hline $\begin{array}{l}\text { Number of aneurysm operations } \\
\text { performed by the surgeon }\end{array}$ & 0.08 & 0.06 & 0.15 & 0.06 & 0.30 \\
\hline
\end{tabular}

GCS - Glasgow Coma Scale; WFNS - World Federation of Neurosurgeons Scale, ICA - internal carotid artery

WFNS, Fisher scales and preoperative neurological status). No significant relationship was found. In particular, ICA segment and specific aneurysm localization did not influence clinical status of the patients on admission or the amount of blood extravasated. The ruptured ICA aneurysm group was homogeneous (Table 4).

\section{Mortality analysis}

We found no cases of intraoperative or early postoperative deaths in our cohort. Late postoperative mortality (later than $48 \mathrm{~h}$ after surgery) reached $14.9 \%$ $(n=36)$. Table 5 provides detailed characteristics of patients who died or survived SAH.

Univariate analysis of demographic data that could influence mortality revealed no relationships between sex $(p=0.94)$, education $(p=0.98)$, domicile $(p=0.77)$ and increased percentage of postoperative deaths. Similarly, coexistence of other diseases $(p=0.82)$ did not affect mortality.

Age had no effect on mortality, either $(p=0.66)$. Average age of patients who died and survived was the same and amounted to $51.9(\mathrm{SD}, 11.8)$ and $51.6(\mathrm{SD}$, $12.5)$ years, respectively. None of the patients below 30 years of age (0/12) died while $21.7 \%$ (5/23) of patients above 70 succumbed.

Clinical status on admission assessed with the HuntHess scale along with consciousness levels judged with
GCS and WFNS scales significantly influenced postoperative mortality in univariate analysis $(p<0.01)$. Neurological deficits prior to surgery increased the probability of death $(p<0.01)$. Risk of death after aneurysm surgery in patients in the $4^{\text {th }}$ or $5^{\text {th }}$ grade in the Hunt-Hess scale was almost six times higher than the patients in better clinical condition $(\mathrm{OR}=5.9,95 \% \mathrm{CI}: 2.8-12.4)$. A similar proportion of postoperative deaths in grades 1 and 2 , and grades 3, 4 and 5 of this scale was found; Osawa in his study [21] reported analogous results. Comparative analysis of mortality for various grades in the WFNS scale revealed significantly lower mortality in the present series in comparison to the patients in the ISAT trial (Figs. 2 and 3) [9].

The extent of bleeding was radiologically appraised according to the Fisher scale; we found that it had a significant influence on death frequency. Univariate analysis proved that the risk of death of patients in the $3^{\text {rd }}$ or $4^{\text {th }}$ grade in the Fisher scale was almost four times higher when compared to grades 1 and $2(\mathrm{OR}=3.8$; 95\% CI: 1.8-8.2). We noted no significant differences in comparison to Osawa's study (Fig. 4) [21].

Next, we evaluated the influence of operative method of aneurysm exclusion from circulation on the risk of postoperative death, separately for each group. Various surgical modalities implemented in order to obliterate ICA aneurysm significantly influenced postoperative mortality $(p<0.01)$ (Fig. 5). Trapping of the artery with or with- 
Table 5. Characteristics of patients who survived or died after the surgical treatment of internal carotid artery aneurysm (percentages mean proportion of the cases)

\begin{tabular}{|c|c|c|}
\hline $\begin{array}{c}\text { Variable } \\
n(\%)\end{array}$ & $\begin{array}{c}\text { Patients who died } \\
n(\%)\end{array}$ & $\begin{array}{l}\text { Survivors } \\
\text { n (\%) }\end{array}$ \\
\hline \multicolumn{3}{|l|}{ WFNS scale } \\
\hline I & $11(7.4 \%)$ & $137(92.6 \%)$ \\
\hline II & $1(8.3 \%)$ & $10(100 \%)$ \\
\hline III & 0 & $11(91.7 \%)$ \\
\hline IV & $16(28.6 \%)$ & $40(71.4 \%)$ \\
\hline $\mathrm{V}$ & $8(50 \%)$ & $8(50 \%)$ \\
\hline \multicolumn{3}{|l|}{ Fisher scale } \\
\hline 1 & 0 & $7(100 \%)$ \\
\hline 2 & $11(8.3 \%)$ & $122(91.7 \%)$ \\
\hline 3 & $19(23.2 \%)$ & $63(76.8 \%)$ \\
\hline 4 & $6(30 \%)$ & $14(70.0 \%)$ \\
\hline Age & $51.9 \pm 11.8^{*}$ & $51.6 \pm 12.5 *$ \\
\hline Surgeon experience (no. of operations performed) & $91.7 \pm 50.5^{*}$ & $82.6 \pm 52.0^{*}$ \\
\hline GCS scale & $10.2 \pm 4.0^{*}$ & $13.4 \pm 2.8^{*}$ \\
\hline \multicolumn{3}{|l|}{ Hunt-Hess scale } \\
\hline 1 & $1(2 \%)$ & $48(98.0 \%)$ \\
\hline $1 \mathrm{~A}$ & 0 & $10(100 \%)$ \\
\hline 2 & $9(10.2 \%)$ & $79(89.8 \%)$ \\
\hline 3 & $7(16.3 \%)$ & $36(83.7 \%)$ \\
\hline 4 & $12(32.4 \%)$ & $25(67.6 \%)$ \\
\hline 5 & $7(46.7 \%)$ & $8(53.3 \%)$ \\
\hline Men & $9(16.1 \%)$ & $47(83.9 \%)$ \\
\hline Women & $27(14.5 \%)$ & $159(85.5 \%)$ \\
\hline Higher education & $4(13.3 \%)$ & $26(86.7 \%)$ \\
\hline Place of residence (countryside) & $2(3.9 \%)$ & $49(96.1 \%)$ \\
\hline Coexisting disease & $23(15.3 \%)$ & $127(84.7 \%)$ \\
\hline Preoperative neurological symptoms & $5(11.6 \%)$ & $38(88.4 \%)$ \\
\hline Postoperative neurological symptoms & $9(50.0 \%)$ & $9(50.0 \%)$ \\
\hline Delayed cerebral ischaemia & $7(30.4 \%)$ & $16(69.6 \%)$ \\
\hline All complications & $5(5.6 \%)$ & $17(94.4 \%)$ \\
\hline General complications & 0 & $13(100 \%)$ \\
\hline Surgical modality & $1(20.0 \%)$ & $4(80.0 \%)$ \\
\hline Clipping & $29(12.8 \%)$ & $197(87.2 \%)$ \\
\hline Trapping & $2(66.7 \%)$ & $1(33.3 \%)$ \\
\hline Wrapping & $1(20.0 \%)$ & $4(80.0 \%)$ \\
\hline Revision only & $2(40.0 \%)$ & $3(60.0 \%)$ \\
\hline Bypass & $2(66.7 \%)$ & $1(33.3 \%)$ \\
\hline
\end{tabular}

*Mean \pm standard deviation

GCS - Glasgow Coma Scale, WFNS - World Federation of Neurosurgeons Scale

out bypass was associated with significantly higher percentage of postoperative deaths, despite the fact that these groups were relatively small ( $n=5$ and $n=3$, respectively). Comparison with another group of patients [21] showed no significant differences in mortality rates.
Mortality in an analysed group of ruptured ICA aneurysms was independent of the year when the surgery was performed $(p=0.15)$, the performing surgeon $(p=0.07)$ and his experience, i.e. the number of aneurysm operations performed by the surgeon 


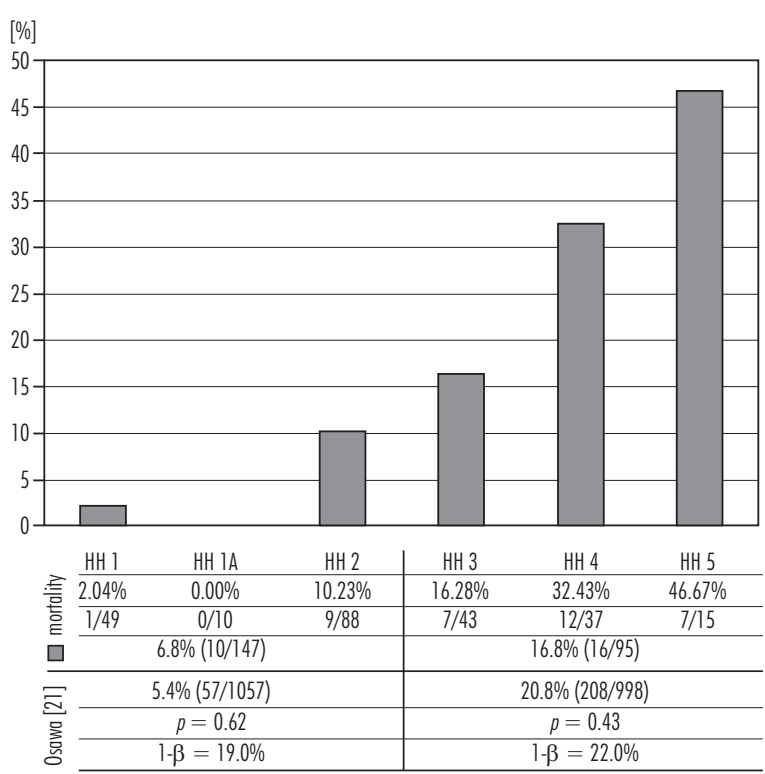

Fig. 2. Postoperative mortality in individual grades of the Hunt-Hess scale. Mortality from Osawa [21] series was shown, comparison analysis $(p)$ and power analysis was performed

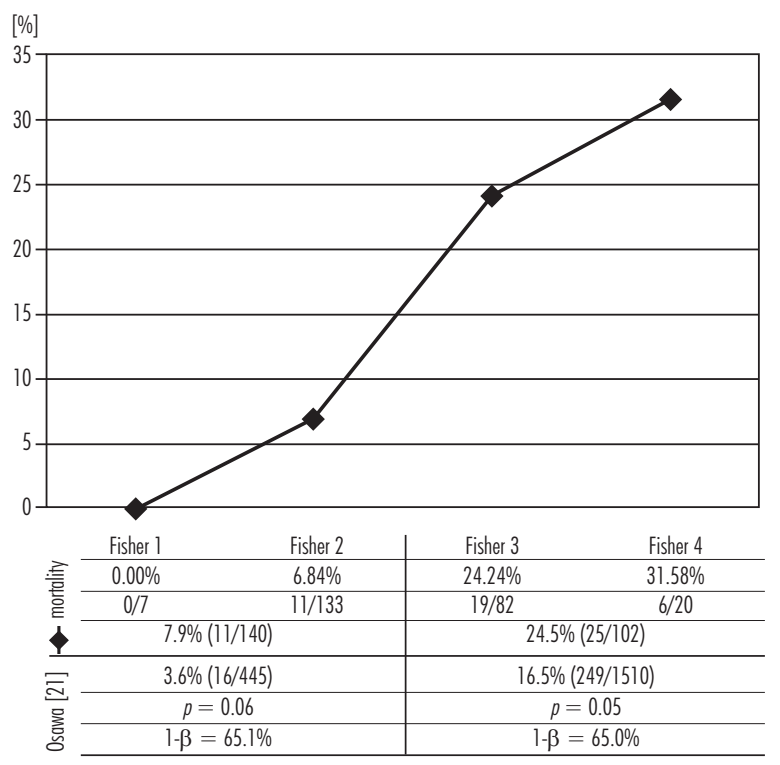

Fig. 4. Postoperative mortality in individual grades of the Fisher scale. Mortality from Osawa's [21] series was shown, comparison analysis $(p)$ and power analysis was performed

$(p=0.08)$, side $(p=0.45)$, artery segment $(p=0.39)$ and aneurysm localization $(p=0.40)$.

We found no significant relationship between postoperative complication occurrence $(p=0.25)$, neither surgical $(p=0.74)$ nor general $(p=0.12)$, and postoperative mortality. On the other hand, the occurrence of new neurological deficits and/or consciousness level

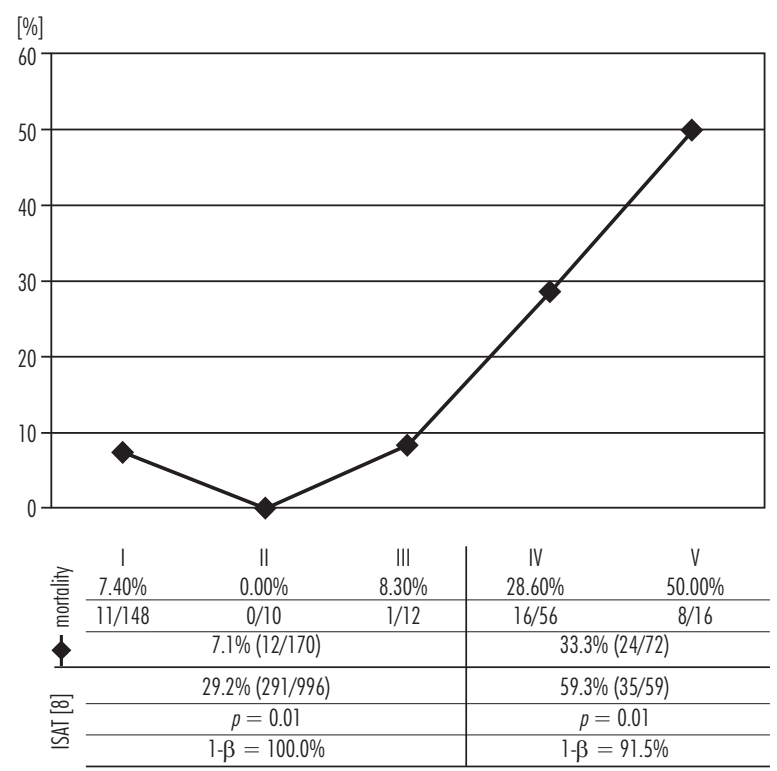

Fig. 3. Postoperative mortality in individual grades of the WFNS scale. Mortality from ISAT [8] series was shown, comparison analysis ( $p)$ and power analysis was performed

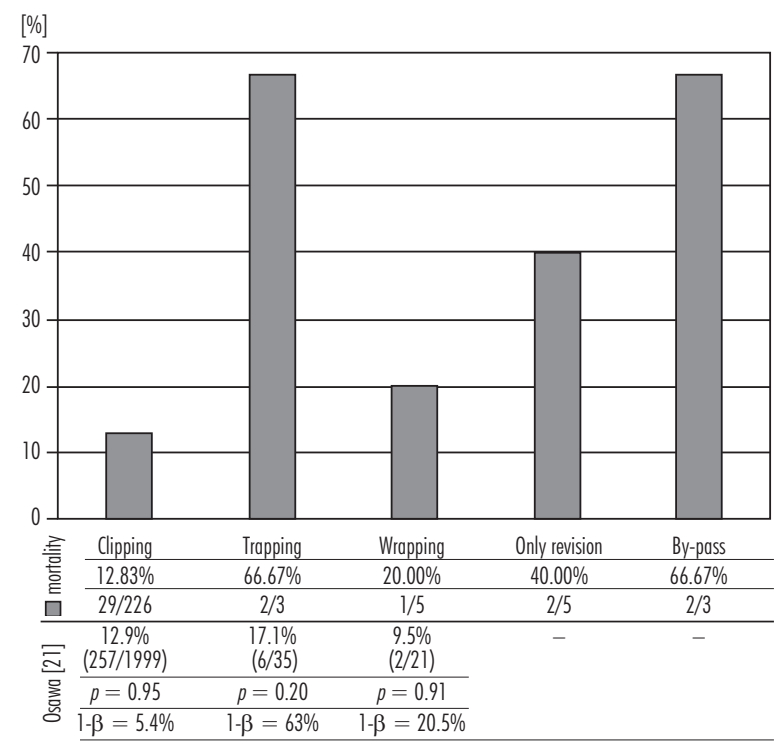

Fig. 5. Influence of aneurysm operative method on mortality risk. Mortality from Osawa's [21] series was shown, comparison analysis ( $p$ ) and power analysis was performed

deterioration (DCI) during hospitalization led to increased mortality in these patients $(p<0.01)$. Death risk in this group of patients was more than five times higher $(\mathrm{OR}=5.2 ; 95 \% \mathrm{CI}: 1.8-14.7)$. We observed $30.4 \%$ (7/23) of deaths in patients with diagnosed DCI and only $5.9 \%(11 / 187)$ in the group without neurological deterioration. 
Table 6. List of significant mortality factors in univariate analysis and all factors in multivariate analyses. P-value ( $p)$ was provided at the moment of removing it from the regression model

\begin{tabular}{|llccc|}
\hline Prognostic factor & $\begin{array}{c}\text { Univariate } \\
\text { analysis }\end{array}$ & $\begin{array}{c}\text { Multivariate } \\
\text { analysis }\end{array}$ & $\begin{array}{c}\text { Odds ratio } \\
\mathbf{( 9 5 \% ~ C l )}\end{array}$ & $\begin{array}{c}\text { Sequence of factor } \\
\text { removal from } \\
\text { regression model }\end{array}$ \\
\hline WFNS scale & $p<0.01$ & $p=0.88$ & $1.1(0.5-2.0)$ & 1 \\
\hline Preoperative neurological symptoms & $p<0.01$ & $p=0.76$ & $1.2(0.4-3.6)$ & 2 \\
\hline Fisher scale & $p<0.01$ & $p=0.71$ & $1.1(0.6-2.3)$ & 3 \\
\hline Trapping & $p<0.01$ & $p=0.26$ & $5.8(0.3-120.1)$ & 4 \\
\hline GCS scale & $p<0.01$ & $p=0.18$ & $1.1(0.9-1.3)$ & 5 \\
\hline Bypass & $p<0.01$ & $p=0.06$ & $12.1(0.9-162.4)$ & 6 \\
\hline Hunt-Hess scale & $p<0.01$ & $p<0.01$ & $2.3(1.7-3.2)$ & $3.1(1.1-9.0)$ \\
\hline Delayed cerebral ischaemia & $p<0.01$ & $p=0.03$ & \\
\hline
\end{tabular}

CI - confidence interval, GCS - Glasgow Coma Scale, WFNS - World Federation of Neurosurgeons Scale

A multivariate analysis of parameters that had a significant influence on postoperative mortality in univariate analyses, i.e. Hunt-Hess grading, GCS, WFNS and Fisher grading, surgical technique (trapping and bypass), preoperative neurological status and DCI diagnosis, was subsequently performed. It revealed two factors that independently and significantly influenced postoperative mortality, i.e. clinical status of the patient on admission assessed with the Hunt-Hess scale and DCI diagnosis during hospitalization (Table 6). Multivariate analysis proved that qualifying a patient who is higher by a single grade in the Hunt-Hess scale for surgery increased his chance of death more than two-fold $(\mathrm{OR}=2.3$; 95\% CI: 1.7-3.2). Moreover, DCI increased the risk of postoperative death three-fold. The percentage of patients correctly classified in the multifactorial model reached $67.4 \%$. Two risk factors (DCI and $4^{\text {th }}$ or $5^{\text {th }}$ grade in Hunt-Hess scale) were responsible for more than $90 \%$ of the postoperative death risk (PAR $=91.1 \%$; $95 \% \mathrm{CI}$ : 78.9-103.1). Lack of DCI postoperatively along with exclusion from the analysis of patients in a poor clinical condition on admission ( $4^{\text {th }}$ and $5^{\text {th }}$ grade in Hunt-Hess scale) reduced mortality after ICA aneurysm surgery by $91.1 \%$.

Multivariate analysis results allowed us to create a simple clinical scale that assigns one point for Hunt-Hess grading higher than 3 (ROC threshold) and another one for diagnosed DCI according to Salary's model [12]. The relationship between ROC curve and mortality was significant $(p<0.01 ; \mathrm{AUC}=0.72 ; 95 \% \mathrm{CI}: 0.67-0.77$ ).

ROC curves were subsequently compared separately for each of the two dependent variables: Hunt-Hess

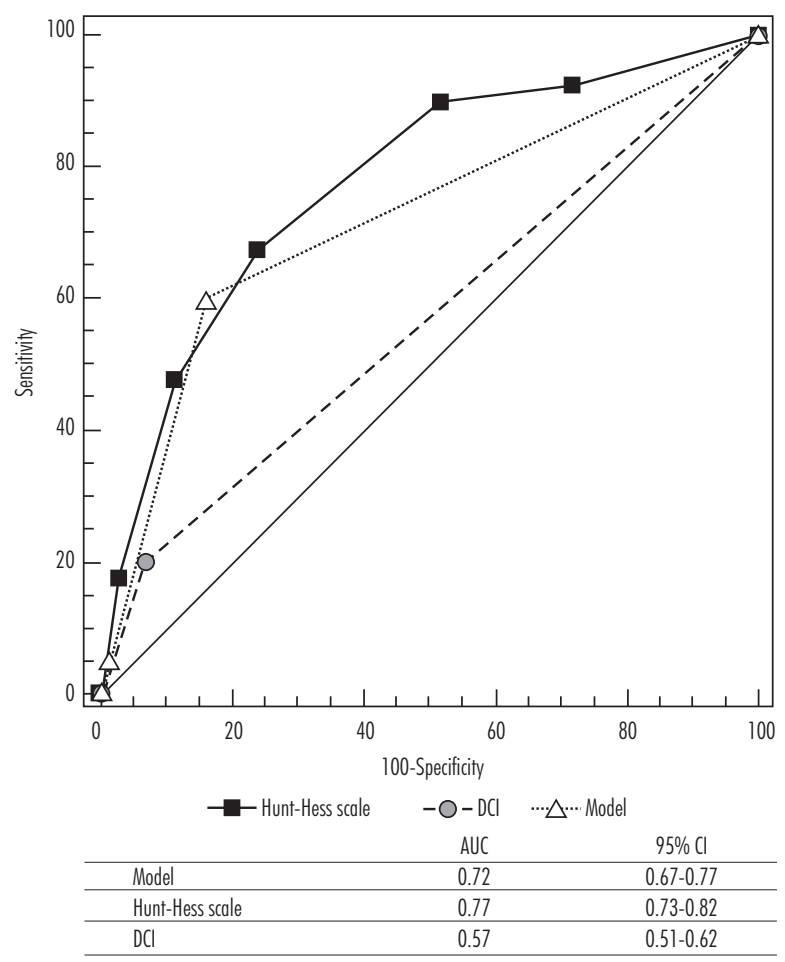

Fig. 6. ROC curves for Hunt-Hess scale, delayed cerebral ischaemia (DCI) and for logistic regression model. Values on the $\mathrm{x}$ and $\mathrm{y}$ axes represent percentages

scale (AUC $=0.77 ; 95 \%$ CI: $0.73-0.82)$ and DCI (AUC $=0.57 ; 95 \% \mathrm{CI}: 0.51-0.62$ ) (Fig. 6). Larger area under the curve (AUC) for the Hunt-Hess scale when compared to AUC for DCI proved that clinical status evaluated with the Hunt-Hess scale was a dominant component of our multifactorial model. This assumption was 
confirmed by a pair comparison of ROC curves for the multifactorial model and Hunt-Hess scale that showed no significant differences $(p=0.12$ ) while ROC curves for the model and DCI differed significantly $(p<0.01)$.

\section{Size of the aneurysm}

The giant aneurysm group did not differ significantly from the smaller aneurysm group with regard to clinical status on admission (Hunt-Hess grading, GCS, WFNS and percentage of neurological deficits) and the extent of the haemorrhage (in Fisher scale) $(p>0.05)$.

Six patients $(16.7 \%, 6 / 36)$ with ruptured giant ICA aneurysms died postoperatively. This result was comparable to the smaller aneurysm group that showed $14.6 \%$ postoperative mortality. Statistical analysis showed no increase of the risk of postoperative death for ruptured giant aneurysms in comparison to the smaller ones $(p=0.74)$. Giant aneurysms of the clinoid segment had the highest mortality (37.5\%). Nonetheless, no significant differences in the percentage of deaths between individual localizations of giant and smaller ICA aneurysms were found (Fig. 1).

We did not note a higher fraction of DCI during hospitalization in the giant aneurysm group. For smaller and giant ICA aneurysms it amounted to $9.2 \%(19 / 206)$ and $11.1 \%(4 / 36)$, respectively.

\section{Discussion}

Intracranial aneurysms constitute a heterogeneous group with various outcomes; in diverse localizations different prognostic factors might affect mortality. The aim of our study was to analyse a group of patients with ruptured aneurysms at the same location. Intracavernous, multiple and blood blister-like aneurysms were excluded from the study. Ultimately, our cohort encompassed a selected group of ICA aneurysms that caused SAH.

Analysis of group homogeneity revealed that patient's clinical status on admission and the amount of extravasated blood did not differ for respective ICA aneurysm localizations. Literature that analyses risk factors for mortality after SAH lacks reports on aneurysms in the same localization. Filling of basal cisterns with blood occurs in ruptured aneurysms located proximally to the middle cerebral artery is related to the highest proportion of patients with vasospasm $[16,25,26]$. It is open to question, however, whether aneurysm localization and related ex- travasated blood distribution constitutes an independent risk factor for a vasospasm [34-36]. Thus, we elected to perform the analysis on a relatively numerous $(n=242)$ group of patients, not different with regard to the vasospasm risk.

Postoperative mortality in our study amounted to $14.9 \%$ while in other large series it varied from $7.9 \%$ to 26.0\% (ISAT [9] 7.9\%; Juvela [38] 9.1\%; Osawa [21] $12.9 \%$; Kassell [13] 26\%). Death percentage is largely dependent on series characteristics; therefore a comparative analysis should be performed in subgroups. A comparison with Osawa's study [21] did not reveal significantly higher mortality in our group. Surprisingly, comparative analysis with the ISAT study [9] for various WFNS grades showed significantly lower mortality in our series. Unfortunately, a combination of all mortality related reports was not feasible due to the various dispositions of results.

Kassell $[13,14]$ was the first to perform a thorough analysis of mortality risk factors in patients treated for $\mathrm{SAH}$. He indicated consciousness level on admission, age, extent of $\mathrm{SAH}$, intraparenchymal and intracerebral bleeding, vasospasm, general coexisting diseases and arterial pressure on admission as factors that influence morbidity. Next, Niskanen [17] in his analysis of more than 800 patients treated surgically after SAH indicated age, Hunt-Hess grading and vasospasm as the most important variables that affected mortality in his group. The summary of aforementioned analyses led to the creation of an accepted neurosurgical doctrine that the triad of factors age, clinical status on admission and vasospasm affects mortality after surgery for ruptured intracranial aneurysms $[12,17]$. Rosen $[18]$ analysed the largest group of patients, exceeding 3500 . He proved that not only the above-mentioned triad of factors influenced mortality but so did hypertension, arterial pressure on admission, aneurysm location and size, the amount of extravasated blood and angiographically confirmed vasospasm on admission.

Later, other authors found further variables that appear to influence mortality of patients after surgery for ruptured intracranial aneurysms. They suggested that cerebral metabolism disruption [37], hyperglycaemia and obesity [38] and increased intracranial pressure [39] might be related to poor outcomes after aneurysm surgery. Next, Hoh [19] described endovascular aneurysm treatment as an additional risk factor for postoperative mortality. Salary [12] in his paper from 2007 weighted the causes for discrepancies between the authors in their ranges of prognostic factors. He methodologically explained that whenever a multifactorial model might 
explain over $75 \%$ of the analysed cases, any innovative new variable through its influence on previous variables might only marginally increase the predictive power of the model [12]. On top of that, in his analysis he confirmed the role of the aforesaid triad of prognostic factors - Hunt-Hess grading, age and vasospasm - as the most significant in the analysis of deaths after surgery for ruptured aneurysm.

With multivariate analysis, we managed to define two significant and independent factors that influence the mortality after surgery for ruptured ICA aneurysm. They included clinical status on admission (in the Hunt-Hess scale) and DCI diagnosis during hospitalization. Clinical evaluation of the patients on admission might be performed with Hunt-Hess, GCS and WFNS scales. Oshiro [40] compared the predictive value of those scales and drew the conclusion that they do not differ in the evaluation of outcome. In our cohort, death risk for patients admitted in the $4^{\text {th }}$ or $5^{\text {th }}$ grade in the Hunt-Hess scale was almost six times higher when compared to the patients with lower grading. Logistic regression revealed a risk of death over two times higher after a change by a single grade in the Hunt-Hess scale. ROC curves analysis pointed out that Hunt-Hess grading constituted a dominant component of our factorial model of mortality. Despite the fact that clinical status on admission strongly correlated with the amount of the extravasated blood judged by the Fisher scale, hierarchical multivariate analysis might discard this scale because of the weight of the Hunt-Hess scale [41]. Several modifications of Fisher and Hunt-Hess scales that show better correlation with DCI occurrence during hospitalization were developed $[16,26,35,40]$. While conclusions for Hunt-Hess grading are indisputable, those drawn for DCI as a clinical manifestation of vasospasm are doubtful. Delayed cerebral ischaemia was diagnosed in patients who deteriorated postoperatively when seizures, recurrent SAH and hydrocephalus were ruled out. In our report, DCI was defined as a clinical manifestation of vasospasm; thus we accepted criteria similar to Claassen's study [16]. The drawback of the aforementioned study, however, was the lack of routine cerebral angiography (AGF) or cerebral blood flow assessment with transcranial Doppler performed in order to confirm the presence of vasospasm in patients who deteriorated neurologically. Claassen stresses that AGF and transcranial Doppler are additional examinations that are not essential for DCI confirmation [16]. Our data strongly support the notion that DCI closely correlated with increased numbers of postoperative deaths in univariate as well as multivariate analysis.
Over $30 \%$ of patients with diagnosis of DCI subsequently died. Death risk in patients with DCI was over five times higher in univariate and almost three times higher in multivariate analysis. Others $[3,4,7,9,12-15,18-21,26,41]$ showed that aside from the clinical status on admission and vasospasm, age of patients was a significant factor that influenced postoperative mortality. In our study, similar to Juvela [38], we were unable to prove such a relationship in multivariate analysis. Moreover, mean age of patients who died and who survived averaged 52 years.

Coexisting general illnesses did not influence postoperative mortality. It is worth mentioning, however, that Rosen and Kassell [13,14,18] listed coexisting illnesses among significant factors that influence postoperative mortality. Both reports describe a sizable population of over 3500 patients; therefore results of those analyses should be considered as the most reliable ones. On the other hand, cited authors $[13,14,18]$ in their final conclusions do not list the size of the aneurysm as a mortality risk factor. Still, a number of authors believe otherwise $[2,3,5,6,9,18$, 20-24], identifying giant aneurysms as a mortality risk factor. It seems unlikely that larger volumes of extravasated blood might play a significant role. Some indicate $[4,23,24]$ that giant aneurysm rupture results in higher amounts of extravasated blood, while others [20,42,43] find in contrast that rupture of smaller aneurysms (mainly the posterior communicating artery) leads to more extensive SAH. This leads to the conclusion that higher mortality in this group of aneurysms relates to surgical complications rather than SAH intensity. Giant aneurysm surgery is among the most difficult in neurosurgery [2-4]. Cohort studies proved that significantly lower postoperative mortalities in neurovascular surgery might relate to surgeon volume [44] as well as to hospital volume [44-46]. Our data did not show any significant differences in death percentages between various aneurysm localizations. Nonetheless, in the giant ICA aneurysm group the highest mortality was found in the subpopulation with clinoid aneurysm localization. Mortality did not differ with various surgical techniques. Four out of six patients after ICA trapping with or without bypass died. This subgroup was too small, however, to draw any conclusions.

Ruptured ICA aneurysms that result in SAH constitute a heterogeneous group of vascular pathologies, where each case may necessitate an individualized approach and might have a different clinical course. Nevertheless, outcomes of patients with various aneurysms in this location are similar and depend on clinical status on admission and the presence of vasospasm. Disqualification of patients in the $4^{\text {th }}$ and $5^{\text {th }}$ grade of the Hunt-Hess scale 
from surgery along with availability of efficient methods of prevention of vasospasm-related DCI would result in mortality reduction by over $90 \%$ (PAR $=91.1 \%)$. Provided that disqualification of patients in poor clinical status on admission remains an alterable risk factor for surgically treated ruptured aneurysm, no efficient methods of DCI treatment exist so far. The present study is based on data collected from a sole neurosurgical centre; accordingly, it only constitutes a supplement for other, multicentre analyses. Lack of correlation between mortality and age of patients, size of an aneurysm, surgical method or other variables for the selected group of aneurysms constitutes a considerable limitation of clinical value of the foregoing study. Wide confidence intervals for OR for critical variables, and absence of influence of surgical method, surgeon experience and postoperative complications on overall mortality may reflect low statistical power of the featured analysis, due to the small size of the group in comparison to the opinion-forming studies of Kassell and Rosen [13,14,18]. Still, analysis of the present group confirmed a vast demand for further studies on novel therapeutic modalities in the treatment of posthaemorrhagic cerebral vasospasm.

\section{Conclusions}

1. The percentage of deaths after surgery for ruptured ICA aneurysm was comparable with other series.

2. Quantitative analysis of mortality should always take into account the whole characteristics of the examined group.

3. Patients' mortality is conditioned by their clinical status on admission (according to the Hunt-Hess scale) as well as by the occurrence of clinical signs of vasospasm during hospitalization.

4. Consciousness status (GCS, WFNS) and the extent of SAH on admission (Fisher scale), preoperative neurological status, side, size, segment and localization of ICA aneurysms, operative method, year of surgery, surgeon and his/her experience, age of patients, sex, education, domicile, and coexisting illnesses might not determine higher postoperative risk in the selected group of patients with ICA aneurysms.

\section{Disclosure}

Authors report no conflict of interest.

\section{References}

1. Flamm E.S. History of Neurovascular Surgery: I. Cerebral aneurysms and subarachnoid hemorrhage. In: Greenblatt S. [ed.]. History of Neurological Surgery. AANS Publishers, Park Ridge 1997.

2. Yasargil M.G. Microsurgery applied to neurosurgery. Georg Thieme Verlag, Stuttgart 1969, pp. 119-143.

3. Le Roux P.D. Management of cerebral aneurysms. Saunders, Pennsylvania 2004.

4. Youmans J.R. [ed.]. Neurological surgery. A comprehensive reference guide to the diagnosis and management of neurological problems, $4^{\text {th }}$ ed. WB Saunders, Philadelphia 1996, vol. 2, chapters 53-54.

5. Parkinson R.J., Eddleman C.S., Batjer H.H., et al. Giant intracranial aneurysms: endovascular challenges. Neurosurgery 2006; 59 (5 Suppl 3): 103-112.

6. Wehman J.C., Hanel R.A., Levy E.I., et al. Giant intracranial aneurysms: endovascular challenges. Neurosurgery 2006; 59 (5 Suppl 3): 125-138.

7. Bakker N.A., Metzemaekers J.D., Groen R.J., et al. International subarachnoid aneurysm trial 2009: endovascular coiling of ruptured intracranial aneurysms has no significant advantage over neurosurgical clipping. Neurosurgery 2010; 66: 961-962.

8. Weir B. Unruptured intracranial aneurysms: a review. J Neurosurg 2002; 96: 3-42.

9. Molyneux A., Kerr R., Stratton I., et al. International Subarachnoid Aneurysm Trial (ISAT) of neurosurgical clipping versus endovascular coiling in 2143 patients with ruptured intracranial aneurysms: A randomised trial. Lancet 2005; 366: 809-817.

10. Wiebers D.O., Whisnant J.P., Huston J., et al. Unruptured intracranial aneurysms: natural history, clinical outcome, and risk for surgical and endovascular treatment (ISUIA). Lancet 2003; 362: 103-110.

11. de Rooij N.K., Linn F.H., van der Plas J.A., et al. Incidence of subarachnoid haemorrhage: a systematic review with emphasis on region, age, gender and time trends. $J$ Neurol Neurosurg Psychiatry 2007; 78: 1365-1372.

12. Salary M., Quigley M.R., Wilberger J.E., Jr. Relation among aneurysm size, amount of subarachnoid blood, and clinical outcome. J Neurosurg 2007; 107: 13-17.

13. Kassell N.F., Torner J.C., Haley E.C., Jr, et al. The International Cooperative Study on the Timing of Aneurysm Surgery. Part 1. Overall management results. J Neurosurg 1990; 73: 18-36.

14. Kassell N.F., Torner J.C., Jane J.A., et al. The International Cooperative Study on the Timing of Aneurysm Surgery. Part 2. Surgical results. J Neurosurg 1990; 73: 37-47.

15. Lagares A., Gomez P.A., Lobato R.D., et al. Prognostic factors on hospital admission after spontaneous subarachnoid haemorrhage. Acta Neurochir (Wien) 2001; 143: 665-672.

16. Claassen J., Bernardini G.L., Kreiter K., et al. Effect of cisternal and ventricular blood on risk of delayed cerebral ischemia after subarachnoid hemorrhage: the Fisher scale revisited. Stroke 2001; 32: 2012-2220.

17. Niskanen M.M., Hernesniemi J.A., Vapalahti M.P., et al. Oneyear outcome in early aneurysm surgery: prediction of outcome. Acta Neurochir (Wien) 1993; 123: 25-32. 
18. Rosen D.S., Macdonald R.L. Grading of subarachnoid hemorrhage: modification of the World Federation of Neurosurgical Societies scale on the basis of data for a large series of patients. Neurosurgery 2004; 54: 566-575.

19. Hoh B.L., Topcuoglu M.A., Singhal A.B., et al. Effect of clipping, craniotomy, or intravascular coiling on cerebral vasospasm and patient outcome after aneurysmal subarachnoid hemorrhage. Neurosurgery 2004; 55: 779-786.

20. Roos E.J., Rinkel G.J., Velthuis B.K., et al. The relation between aneurysm size and outcome in patients with subarachnoid hemorrhage. Neurology 2000; 54: 2334-2336.

21. Osawa M., Hongo K., Tanaka Y., et al. Results of direct surgery for aneurysmal subarachnoid haemorrhage: outcome of 2055 patients who underwent direct aneurysm surgery and profile of ruptured intracranial aneurysms. Acta Neurochir (Wien) 2001; 143: 655-663.

22. Sharma B.S., Gupta A., Ahmad F.U., et al. Surgical management of giant intracranial aneurysms. Clin Neurol Neurosurg 2008; 110: 674-681.

23. Fujita K., Yamashita H., Masumura M., et al. Natural history of giant intracranial aneurysms. No Shinkei Geka 1988; 16: 225-231

24. Keravel Y., Sindou M. Giant intracranial aneurysms. SpringerVerlag, Berlin 1988, pp. 1-163.

25. Fisher C.M., Kistler J.P., Davis J.M. Relation of cerebral vasospasm to subarachnoid haemorrhage visualized by computerized tomographic scanning. Neurosurgery 1980; 6: 1-9.

26. Hijdra A., Brouwers P.J., Vermeulen M., et al. Grading the amount of blood on computed tomograms after subarachnoid hemorrhage. Stroke 1990; 21: 1156-1161.

27. Krings T., Piske R.L., Lasjaunias P.L. Intracranial arterial aneurysm vasculopathies: targeting the outer vessel wall. Neuroradiology 2005; 47: 931-937.

28. Hunt W.E., Hess R.M. Surgical risk as related to time of intervention in repair of intracranial aneurysms. J Neurosurg 1968; 28: $14-20$.

29. Hunt W.E., Kosnik E.J. Timing and perioperative care in intracranial aneurysm surgery. Clin Neurosurg 1974; 21: 79-89.

30. Wilson J.T., Pettigrew L.E., Teasdale G.M. Structured interviews for the Glasgow Outcome Scale and the extended Glasgow Outcome Scale: guidelines for their use. J Neurotrauma 1998; 15: 573-585.

31. Cavanagh S.J., Gordon V.L. Grading scales used in the management of aneurysmal subarachnoid hemorrhage: a critical review. J Neurosci Nurs 2002; 34: 288-295.

32. Słoniewski P., Dzierżanowski J., Szmuda T. Modyfikacja dojścia pterionalnego do patologii dołu międzykonarowego - technika, morfometria i wyniki leczenia. Neurol Neurochir Pol 2008; 42 (supl. 2): 160-168.

33. Lokato E.B., Gravenstein N., Kirby R.R. Complications in anesthesiology. $3^{\text {rd }}$ ed. Wolters Kluwer Health, Lippincott Williams \& Wilkins 2007, p. 4.

34. Brouwers P.J., Wijdicks E.F., van Gijn J. Infarction after aneurysm rupture does not depend on distribution or clearance rate of blood. Stroke 1992; 23: 374-379.

35. Kramer A.H., Hehir M., Nathan B., et al. A comparison of 3 radiographic scales for the prediction of delayed ischemia and prognosis following subarachnoid hemorrhage. J Neurosurg 2008; 109: 199-207.

36. Yin L., Ma C.Y., Li Z.K., et al. Predictors analysis of symptomatic cerebral vasospasm after subarachnoid hemorrhage. Acta Neurochir Suppl 2011; 110: 175-178.

37. Sarrafzadeh A., Haux D., Küchler I., et al. Poor-grade aneurysmal subarachnoid hemorrhage: relationship of cerebral metabolism to outcome. J Neurosurg 2004; 100: 400-406.

38. Juvela S., Siironen J., Kuhmonen J. Hyperglycemia, excess weight, and history of hypertension as risk factors for poor outcome and cerebral infarction after aneurysmal subarachnoid hemorrhage. J Neurosurg 2005; 102: 998-1003.

39. Heuer G.G., Smith M.J., Elliott J.P., et al. Relationship between intracranial pressure and other clinical variables in patients with aneurysmal subarachnoid hemorrhage. J Neurosurg 2004; 101: 408-416.

40. Oshiro E.M., Walter K.A., Piantadosi S., et al. A new subarachnoid hemorrhage grading system based on the Glasgow Coma Scale: a comparison with the Hunt and Hess and World Federation of Neurological Surgeons Scales in a clinical series. Neurosurgery 1997; 41: 140-147.

41. Chiang V.L., Claus E.B., Awad I.A. Toward more rational prediction of outcome in patients with high-grade subarachnoid hemorrhage. Neurosurgery 2000; 46: 28-35.

42. Russell S.M., Lin K., Hahn S.A., et al. Smaller cerebral aneurysms producing more extensive subarachnoid hemorrhage following rupture: a radiological investigation and discussion of theoretical determinants. J Neurosurg 2003; 99: 248-253.

43. Taylor C.L., Steele D., Kopitnik T.A., Jr, et al. Outcome after subarachnoid hemorrhage from a very small aneurysm: a casecontrol series. J Neurosurg 2004; 100: 623-625.

44. Barker F.G., 2nd, Amin-Hanjani S., Butler W.E., et al. Agedependent differences in short-term outcome after surgical or endovascular treatment of unruptured intracranial aneurysms in the United States, 1996-2000. Neurosurgery 2004; 54: 18-28.

45. Barker F.G., 2nd, Amin-Hanjani S., Butler W.E., et al. In-hospital mortality and morbidity after surgical treatment of unruptured intracranial aneurysms in the United States, 1996-2000: the effect of hospital and surgeon volume. Neurosurgery 2003; 52: $995-1009$.

46. Cross D.T., 3rd, Tirschwell D.L., Clark M.A., et al. Mortality rates after subarachnoid hemorrhage: variations according to hospital case volume in 18 states. J Neurosurg 2003; 99: 810-817. 